\title{
Paradiplomacy and The Future of Cooperation Between Regions
}

\author{
Muhammad Yami and Arif Darmawan \\ International Relations Department, University of Jenderal Soedirman, Purwokerto-Central Java, Indonesia \\ (yamin.unsoed@gmail.com)
}

\begin{abstract}
As the roles of a state as an international actor lessens, cooperation between individuals or groups from several countries or across regions gets stronger. The understanding of one-door policy these days doesn't necessarily translate to a policy that is controlled by a diplomatic legal institution. The desire to cooperate without the involvement of a complicated bureaucracy makes regional institutions create cooperation between regions in different areas, these spirits are then came to be known as Paradiplomacy.Regionalism that continues to emerge after the birth of European Union or countries that agreed to unite in one Europe area makes other regions have a strong desire to copy this idea. The success of Europe have inspired Southeast Asian countries that are members of ASEAN to create ASEAN Community that will be implemented in the upcoming year of 2015.The strong utopianism towards regionalism actually creates an emerging question about the role and existence of state, or even in a more sarcastic tone, is there still a need for a state. Region or province that are within the territory of a state saw this as a chance to bring prosperity to their own area. The most commonly heard example is cooperation between cities across states, known as sister city. Sister city is not the only example that can be put forward as a future of relation between regions, as there are still a lot of examples or cases that can be brought up as an improvement in cooperation between regions that crosses the borders of countries of areas. The battle between idealism and regulism that happens in every states actually brings a new dynamic and breakthrough in the world of international relations, this idea enriches the discourse of international analyst in preparing their own areas. These are an inseparable part in an attempt to exceed the boundaries of law of each countries that became the general definition of international relations.
\end{abstract}

Keywords: Cooperation, region, area, diplomacy

\section{Preface}

The end of the Thirty Years' War in Europe, marked with the creation of the Treaty of Westphalia created the conception of nation-state. This clear and distinct division ended the long journey of the concept of nation-language that became a part of European countries' history, especially Western Europe.

The conception of nation-state referred to in the Treaty of Westphalia made the developing understanding of international relations glorify nation-state as a main actor on the behavior of relation between nations that happens these days. The behavior of nation-state is based on three reasons. First, the study object of international relations is nation state. Second, nationalism is a central fact in international politics and the best way to understand nationalism is to analyze the behaviors of the created community which is nation-state. Third, because nation-state is an atom of a universe that is international politics. ${ }^{\mathrm{i}}$

Even though along the way the understanding about nation and state experienced a distortion that caused a very principal difference of concept in researches about the developing international relations. For scholars and practitioners of international relations, it is very common to use concepts of states (or taking lessons from the history of states practice) as if this term describes a phenomenon of an institute that is constant and unchanged.

This tendency is seen especially visible on the second half of the twentieth century, when scholars first started to articulate the need for scientific approach on this subject in the 1940s, a movement 
that was developed further by behavioral scientific revolution that emerged between the 1950s and 1960s. Neorealist who wrote in the 1970s and 1980s are commonly associated with the general thinking of positivistic about state and the behavior of state from time to time and everywhere. For Kenneth Waltz, the immortal anarchy character of international politics explained a striking similarity in terms of the quality of international living for thousands of years. Whereas for Robert Gilpin, states during their history have a main goal of conquering regions to further advance their economies, security, and other interests. ${ }^{\text {ii }}$

On the other hand, the usage of the term nation also shows the inconsistency by the scholars and practitioners to describe the main unit in international relations. Despite it being often linked with the state centrism, Hans Morgenthau wrote further about nation than about state in his classic work Politics Among Nations. Even so, the roots of Weberian from the main unit of his analysis -stateis clearly visible and strongly planted in the aforementioned Morgenthau classic. ${ }^{\text {iii }}$

Dualism in the dichotomy of state and nation in the perspective of international relations showed a basic weakness. Said weakness is located in the inability to control the negative tendency that appears from the behavior of states' decision makers. States' elites can freely take actions or decisions that at any given time can create tragedy or disaster for millions of other people, both in their own state or others by hiding behind what is called national interest or national security. ${ }^{\text {iv }}$

To reduce the negative understanding and limit the dichotomy of state and nation, international relations analysts then presented an alternative understanding as a new offer on how international relations is operated, one of which is by prioritizing the role of regionalism. Giving a meaning to regionalism emerged alongside international turmoil that pushed universalism forward in the development and journey of politics and international system. European Union becomes the most legitimate example to explain the success of existing regionalism today.

It is precisely the success of European Union that became an example for other regions to follow in their footsteps. One of those is ASEAN (Association of Southeast Asian Nations), who declared ASEAN Community 2015, where countries in the Southeast Asia region agreed on the unification of three pillars (economy, security, and culture) to realize the meaning of regionalism. Can this idealism succeed? We'll let history answer that question.

Furthermore, it isn't about a battle of narrow ideology, but the diminishing role of state in international system, whereas state is traditionally understood as a main unit or an atom in international politics. The question that appears, then, is how relevant is the role of state today, mainly in terms of connectivity between states or in other words, international cooperation.

\section{Paradiplomacy and International Cooperation}

The weakening of state's role left a lot of decision makers confused on how to react to this situation. Often times, the policies that have something to do with the agreement on cooperation between states or even with a lot of states wasn't based on the need or interest of a state but based on the urges from the international system that have too strong of an effect on the decision-making individuals.

Decision making on the central lever which possesses a tendency of momentary interest causes 
an imbalance in opportunity, wealth, and harmony that is needed in regions. Such structural jealousy is often described as centralistic. To ease this problem, states often change the centralistic system to decentralization so that regions feel more appreciated and to some extend have a role in the state's development.

Even though the existence of decentralization is still seemed half-hearted on its execution or actually created a number of small 'kings' that have too much power and control in a region. The chance to advance cooperation with other regions and even with regions from other states become wide open. It is here, then, that a new breakthrough in international cooperation was born, and it was named Paradiplomacy.

This yet unpopular term is often being seen as similar to diplomacy. Even though the essence of the terminology is the same, which is cooperation, put it simply Paradiplomacy is understood more as cooperation between regions in different states. Paradiplomacy refers to the behavior and capacity to create cooperation with other party abroad in the level of sub-state entity, or regional administration for their own specific interest. ${ }^{\mathrm{v}}$ The term Paradiplomacy was first launched in an academic discourse between Basque scholar, PanayotisSoldatos in the 1980s as a merge between the words parallel and diplomacy, thus the word Paradilomacy, which refers to the foreign policy of non-central government, according to Aldecoa, Keating, and Boyer. Another term for this concept was given by Ivo Duchacek, microdiplomacy. ${ }^{\mathrm{vi}}$

Sister city/province or cooperation between cities in different states became an example of how it is possible for regions in different states to cooperate. This cooperation between cities is often made as a role model on how regions can develop their own potential without having to wait for a complex bureaucracy from central government, who doesn't always act and response quickly on problems in the regions. The best example of sister city's success in the cross-province cooperation between Daerah Istimewa Yogyakarta (DIY) in Indonesia with Kyoto Prefecture in Japan. This cooperation, which has been going for more than 20 years, has profited both province in a lot of ways. Such as cultural mission exchange, scholarship funding, student exchange, technology transfer, etc. ${ }^{\text {vii }}$ The most felt and noticeable example of said cooperation was after the tectonic earthquake of May 27, 2006, registered 6.1 on the Richter scale, destroyed a massive number of infrastructures and caused the death of over 6,000 lives in Yogyakarta. It was then that the Kyoto Prefecture government had the initiative to help alleviate the burden felt by DIY by sending delegates to help deliver post-earthquake recovery help by the form of financial grant totaling $¥ 9.2$ million, which was a result of donation made by the people of Kyoto Prefecture. ${ }^{\text {vii }}$

The success of several regions in Indonesia in creating cooperation with regions in other countries outside of Indonesia showed the importance of cooperation between regions in different countries in this day and age. The question about the future of international relations that have been dominated thus far by states needs to be answered as soon as possible. Why? Because if every nation is still trapped in a centralistic understanding, the growth and prosperity of a region will then be extremely hampered and trailing behind regions in other countries.

The moment of ASEAN Community, which will begin in the year 2015 can be viewed as a 
momentum to try and create a lot of cooperation between regions within Southeast Asia, as a pilot project to reach a lot more cooperation within the scope of international system.

From a geographical standpoint, regionalism in ASEAN is an effective way to build a solid and cohesive integrated regions. The modern concept of regionalism is not a rigid condition, instead it's a dynamic and continuously developing condition. To increase its influence in the international arena, ASEAN realized the need to collaborate with bigger countries, especially in the economic sector.

\section{Conclusions}

A new breakthrough in international relations study showed the world that every individual affiliated in a society deserves to determine the acceleration of their own prosperity through international cooperation which are no longer limited by centralism, either in thoughts or regulation.

A lot of international relations scholar still consider state sovereignty as a foundation for their own field. Most Western political philosophies are focused on the state itself with its relation with the citizen, and international relations is a logical extension which deals with relation between states. In reality, sovereignty is more of an aspiration than reality. For a lot of ruler, sovereignty is a useful instrument of law, as stated by a realist, Stephen Krasner, 'sovereignty is used to legitimize a king's right to collect taxes, and by that strengthen a nations' position and not give similar right to churches so that it weakens the position of Pope'. ix

The construction of foreign relation which bears the characteristics of international relations these days have a more participative characteristic for all international actors, either in state and local level or institutional and individual level. The spirit of positive sum and pure collaboration which are promoted as transnational values will give more hope for the creation of a more civilized world. ${ }^{\mathrm{x}}$

The shift in an actor's role in international relations which is no longer state centric doesn't necessarily erase the main joint of state sovereignty, but creates a demand for a more comprehensive, wider, and more flexible arrangement to share sovereignty within the limits of their constitution with region government. The practice of paradiplomacy in developed countries brings an unavoidable consequence that there will be a struggle for the sharing of sovereignty. ${ }^{x i}$

\section{References}

${ }^{1}$ Takdir Ali Mukti, Paradiplomacy: Kerjasama Luar Negeri oleh Pemda di Indonesia, Phinisi Press, Yogyakarta, 2013. P 250

${ }^{1}$ Ibid. P. 252

1 Stephen D. Krasner. Westphalia and all That", dalam Judith Goldstein and Robert O. Keohane, Ideas and Foreign Policy (Ithaca, NY: Cornell University Press, 1993), 238 dalam Richard W Mansbach and Kirsten L. Rafferty, "Pengantar Politik Global: Introduction to Global Politics, Nusamedia, Bandung, Agustus 2012, P 904

${ }^{1}$ Takdir Ali Mukti, Paradiplomacy: Kerjasama Luar Negeri oleh Pemda di Indonesia, Phinisi Press, Yogyakarta, 2013. P 345

${ }^{1}$ Ibid, P. 345-346

${ }^{1}$ MohtarMas'oed, Studi Hubungan Internasional, Tingkat AnalisadanTeoritisasi, PAU-UGM, Yogyakarta, 1999, hal 1-2

1 Walter Carlsnaes< Thomas Risse, Beth A Simmons. Handbook Hubungan Internasional (terj), Nusamedia, Bandung, 2013, Hal 325.

${ }^{1}$ Ibid, Hal326

${ }^{1}$ Prof. DR. Bambang Cipto, MA. Dunia Islam dan 
Masa Depan Hubungan Internasional di Abad 21,LPPM UMY, Yogyakarta, 2011. Hal 25

1 Stefan Wolff, Paradiplomacy: Scope, Opportunities and Challenge', University of Nottingham, 2009, P.1-2 and 13

${ }^{1}$ David Criekemans, Are The Boundaries Between Paradiplomacy and Diplomacy Watering Down?.University of Anwerp and Flemish Center for International Policy, Belgium, 2008 P. 34 